\title{
IDENTIFIKASI DAN ISOLASI BAKTERI PENYEBAB PENDERITA DENGAN GEJALA SUSPEK DEMAM TYPHOID DI RUMAH SAKIT IBNU SINA MAKASSAR TAHUN 2016.
}

\author{
Yusriani Mangarengi, Achmad Harun, Andi Azizah Noor, Andi Nurul Fasty Batari
}

\begin{abstract}
ABSTRAK
Latar Belakang: Bakteri Salmonella sp. adalah bakteri bentuk batang, gram negatif, hidup dalam saluran pencernaan manusia maupun hewan. ${ }^{1}$ Salmonella sp. yang masuk bersama makanan dan minuman yang tercemar akan menyebabkan Demam enterik. ${ }^{2}$ Demam enterik dapat di kelompokan menjadi dua yaitu Demam typhoid atau tipus (typhus) yang disebabkan oleh bakteri Salmonella typhi (S. typhi), sedangkan Demam paratyphoid disebabkan oleh bakteri Salmonella paratyphi $A, B, \operatorname{dan} C$ (S. paratyphi $A, B, \operatorname{dan} C$ ). Tujuan: Untuk mengetahui prevalensi angka kejadian gejala suspek Demam Typhoid di RS. Ibnu Sina dan prevalensinya berdasarkan usia, jenis kelamin, serta mengisolasi dan mengidentifikasi kuman penyebab pasien gejala suspek Demam Typhoid di RS.Ibnu Sina Makassar Juli- Agustus tahun 2016. Metode Penelitian: Penelitian ini merupakan penelitian secara eksperimental deskriptif. Hasil Penelitian: Prevalensi angka kejadian Demam Tyfoid di RS. Ibnu Sina Juli-Agustus 2016 sebanyak 40 pasien dan menggunakan rumus Slovin jumlah besar sampel yang diperlukan sebanyak 29 pasien. Presentasi responden pasien dengan gejala suspek Demam Typhoid berdasarkan jenis kelamin yaitu laki-laki sebanyak 17 dari 29 pasien $(58,6 \%)$ dan perempuan sebanyak 12 pasien (41,4\%). Presentasi responden pasien dengan gejala suspek Demam Typhoid berdasarkan umur yaitu berusia 1-9 tahun sebanyak 5 pasien (17,2\%), usia 10-18 tahun sebanyak 4 pasien (13,8 \%), usia 19-27 tahun sebanyak 11 pasien (37,9\%), usia 28-37 tahun sebanyak 3 pasien (10,3\%), usia 38-47 tahun sebanyak 1 pasien $(3,4 \%)$ dan usia 48-58 sebanyak 5 pasien (17,2\%). Presentasi responden pasien dengan gejala suspek Demam Typhoid berdasarkan jenis bakteri yaitu bakteri Alkaligenes faecalis sebanyak 4 pasien (13,8 \%), bukan bakteri sebanyak 16 pasien (55,2 \%), Klebsiella aerogenes sebanyak 3 pasien (10,3\%), Klebsiella pneumonia sebanyak 1 pasien (3,4 \%), Salmonella Paratyphi A sebanyak 1 pasien $(3,4 \%)$, dan Salmonella typhi sebanyak 4 pasien (13,8 \%). Kesimpulan: Dari hasil penelitian ini dapat disimpulkan bahwa prevalensi angka kejadian Demam Typhoid di RS. Ibnu Sina Juli-Agustus 2016 sebanyak 40 pasien. Pada kasus 29 pasien bergejala suspek Demam Typhoid di Rumah Sakit Ibnu Sina Juli-Agustus 2016, laki-laki memiliki prevalensi lebih tinggi daripada perempuan, menurut usia, usia 19-27 tahun
\end{abstract}


memiliki tingkat prevalensi tertinggi 37,9 \%, dan menurut hasil isolasi dan identifikasi sampel, kuman penyebab tidak hanya ditemukan bakteri Salmonella typhi / Salmonella paratyphi, tetapi terdapat etiologi lain ( Salmonella typhi 13,8 \%; Salmonella paratyphi A 3,4 \%, Tidak Ada Pertumbuhan (TAP) 55,2 \%; Alkaligenes faecalis sebanyak 13,8 \%;Klebsiella aerogenes sebanyak 10,3\%; Klebsiella pneumonia sebanyak 3,4\%.

Kata kunci: Umur, Jenis Kelamin, Bakteri, Typhoid

\section{Latar Belakang}

Bakteri Salmonella sp. adalah bakteri bentuk batang, gram negatif, hidup dalam saluran pencernaan manusia maupun hewan. ${ }^{1}$ Salmonella sp. yang masuk bersama makanan dan minuman yang tercemar akan menyebabkan demam enterik. ${ }^{2}$ Demam enterik dapat di kelompokan menjadi dua yaitu Demam Typhoid atau tipus (typhus) yang disebabkan oleh bakteri Salmonella typhi (S. typhi), sedangkan Demam Paratyphi disebabkan oleh bakteri Salmonella paratyphi $A, B$, dan $C$ (S. paratyphi $A, B$, dan $C$ ). ${ }^{3}$ Gejala dan tanda klinis keduanya sama yang paling menonjol adalah demam lebih dari tujuh hari. Tujuan penelitian ini adalah untuk mengisolasi dan mengidentifikasi kuman penyebab pasien gejala suspek Demam Typhoid di RS.Ibnu Sina Makassar tahun 2016.

Manusia terinfeksi Salmonella typhi secara fekal-oral. Tidak selalu Salmonella typhi yang masuk ke saluran cerna akan menyebabkan infeksi karena untuk menimbulkan infeksi, Salmonella typhi harus dapat mencapai usus halus. Salah satu faktor penting yang menghalangi Salmonella typhi mencapai usus halus adalah keasaman lambung. Bila keasaman lambung berkurang atau makanan terlalu cepat melewati lambung, maka hal ini akan memudahkan infeksi Salmonella typhi.Setelah masuk ke saluran cerna dan mencapai usus halus, Salmonella typhi akan ditangkap oleh makrofag di usus halus dan memasuki peredaran darah, menimbulkan bakteremia primer. Selanjutnya, Salmonella typhi akan mengikuti aliran darah hingga sampai di kandung empedu. Bersama dengan sekresi empedu ke dalam saluran cerna, Salmonella typhi kembali memasuki saluran cerna dan akan menginfeksi Peyer's patches, yaitu jaringan limfoid yang terdapat di ileum, kemudian kembali memasuki peredaran darah, menimbulkan bakteremia sekunder. Pada saat terjadi bakteremia sekunder, dapat ditemukan gejala-gejala klinis dari Demam Typhoid. ${ }^{16}$ Salmonella typhi mempunyai 3 macam antigen, yaitu: 
1. Antigen $O$ (Antigen somatik), yaitu terletak pada lapisan luar dari tubuh kuman. Bagian ini mempunyai struktur kimia lipopolisakarida atau disebut juga endotoksin. Antigen ini tahan terhadap panas dan alkohol tetapi tidak tahan terhadap formaldehid. ${ }^{9}$

2. Antigen $H$ (Antigen flagela), yang terletak pada flagela, fimbriae atau pili dari kuman. Antigen ini mempunyai struktur kimia suatu protein dan tahan

terhadap formaldehid tetapi tidak tahan terhadap panas dan alkohol yang telah memenuhi kriteria penilaian. ${ }^{9}$

3 . Antigen Vi yang terletak pada kapsul (envelope) dari kuman yang dapat melindungi kuman terhadap fagositosis. ${ }^{9}$

Ketiga macam antigen tersebut di atas di dalam tubuh penderita akan menimbulkan pula pembentukan 3 macam antibodi yang lazim disebut aglutinin. ${ }^{9}$

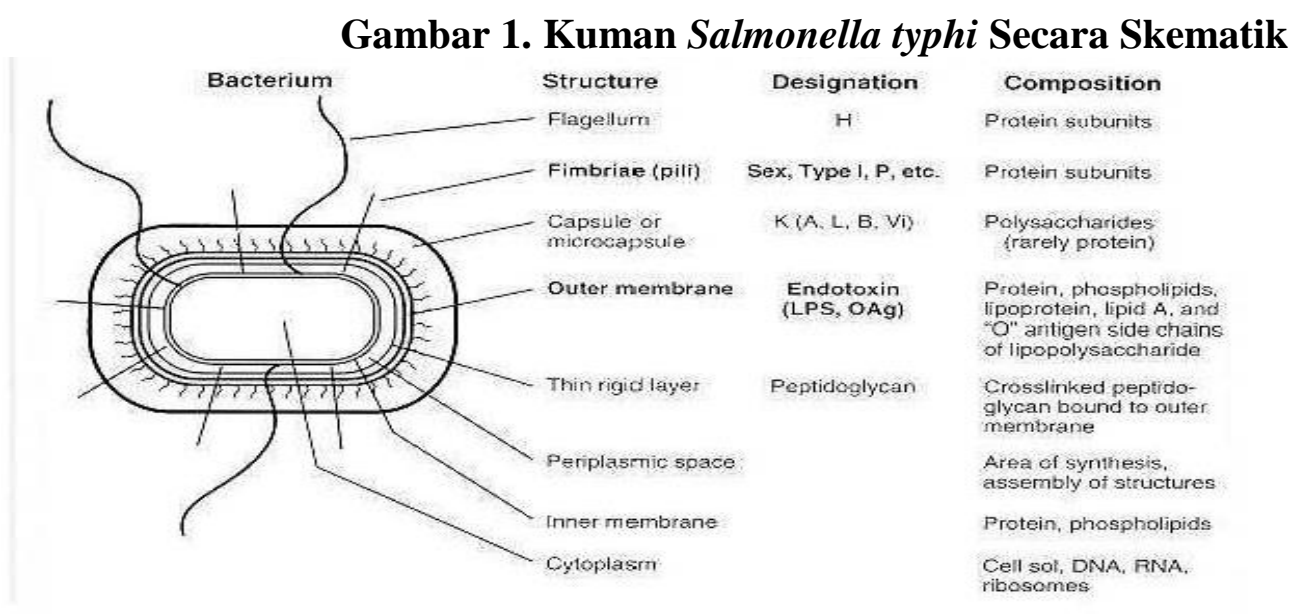

Sumber: Rustandi R. dan Wilda S., 2010

\section{$\underline{\text { Metode Penelitian }}$}

Penelitian ini merupakan penelitian secara eksperimental deskriptif.

\subsection{Lokasi dan Waktu Penelitian}

Penelitian ini dilakukan di bagian rawat jalan dan rawat inap Rumah Sakit Ibnu Sina Makassar, waktu penelitian adalah bulan Juni - Agustus tahun 2016.

\subsection{Populasi dan Sampel}

\subsubsection{Populasi dan sampel yang diteliti}


Populasi penelitian ini adalah data yang diperoleh dari rekam medik pasien rawat jalan dan rawat inap penderita Demam Typhoid di Rumah Sakit Ibnu Sina Makassar pada bulan Juni Agustus tahun 2016.

Sampel yang diteliti dari laboratorium Patologi Klinik dan laboratorium Mikrobiologi RS. Ibnu Sina selama sesuai dengan teknik pengambilan sampel.

Pengolahan data dilakukan dengan penelitian eksperimental di Laboratorium Fakultas Kedokteran Universitas Muslim Indonesia.

\section{4. 3. Interpretasi Data}

Interpretasi data dilakukan secara deskriptif.

\section{4. 4. Pelaporan Hasil Penelitian}

Pelaporan hasil penelitian disusun dalam bentuk laporan penelitian ilmiah.

\section{5. Teknik pengambilan sampel}

Pengambilan sampel untuk penelitian ini menggunakan teknik purposive sampling dengan pertimbangan pengambilan sampel dilakukan sedemikian rupa sehingga kewakilannya ditentukan berdasarkan pertimbangan orang yang berpengalaman dan perhitungan berdasarkan rumus Slovin.

\section{HASIL PENELITIAN DAN PEMBAHASAN}

\subsection{Hasil Penelitian}

Penelitian ini dilakukan di Rumah Sakit Ibnu Sina Makassar, dilaksanakan pada bulan Juni hingga Agustus 2016 dan pengambilan data sampel dari bulan Juli-Agustus 2016. Data dalam penelitian ini adalah pasien bergejala Demam Typhoid di RS Ibnu Sina sebanyak 29 sampel.

\subsubsection{Analisis Univariat}

Analisis univariat adalah analisis yang bertujuan untuk menjelaskan atau mendeskriptifkan karakteristik variabel yang diteliti.

Menurut data sekunder yang kami dapatkan menunjukkan bahwa prevalensi angka kejadian pasien bergejala suspek demam typhoid di RS Ibnu Sina bulan Juli-Agusutus 2016 sebanyak 40 pasien. Menurut rumus total sampling, sampel yang dibutuhkan untuk pengambilan data sebanyak 29 pasien. 
Tabel 4.1. Prevalensi pasien gejala suspek Demam Typhoid berdasarkan jenis kelamin

\begin{tabular}{l|l|l} 
& Frequensi $(\mathbf{n = 2 9 )}$ & Persen \\
\hline Laki-laki & 17 & 58,6 \\
\hline Perempuan & 12 & 41,4 \\
\hline Total & 29 & 100
\end{tabular}

Sumber: data primer penelitian

Gambar 6. Diagram prevalensi pasien gejala suspek Demam Typhoid berdasarkan jenis kelamin

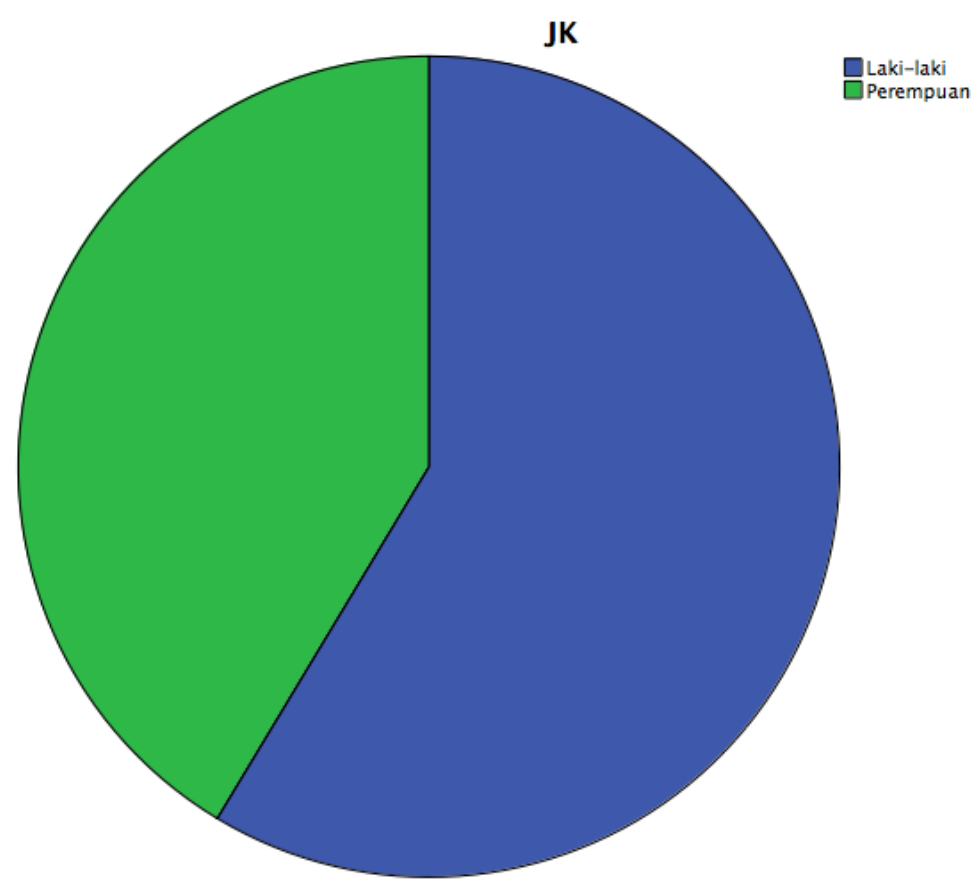

Sumber: data primer penelitian

Berdasarkan tabel 4.1. di atas, menunjukkan bahwa presentasi responden terbanyak dari 29 pasien adalah laki-laki sebanyak 17 pasien (58,6\%) dan perempuan sebanyak 12 pasien $(41,4 \%)$.

Tabel 4.2. Prevalensi pasien gejala suspek Demam Typhoid berdasarkan umur $(\mathrm{n}=29)$

\begin{tabular}{c|c|c} 
Umur (tahun) & Frequensi & Persen \\
\hline $10-18$ & 4 & 13.8 \\
\hline $19-27$ & 11 & 37.9 \\
\hline $28-37$ & 3 & 10.3 \\
\hline $38-47$ & 1 & 3.4 \\
\hline $48-58$ & 5 & 17.2
\end{tabular}


Total

Sumber: data primer penelitian

\section{Gambar 7. Diagram prevalensi pasien gejala suspek Demam Typhoid berdasarkan umur}

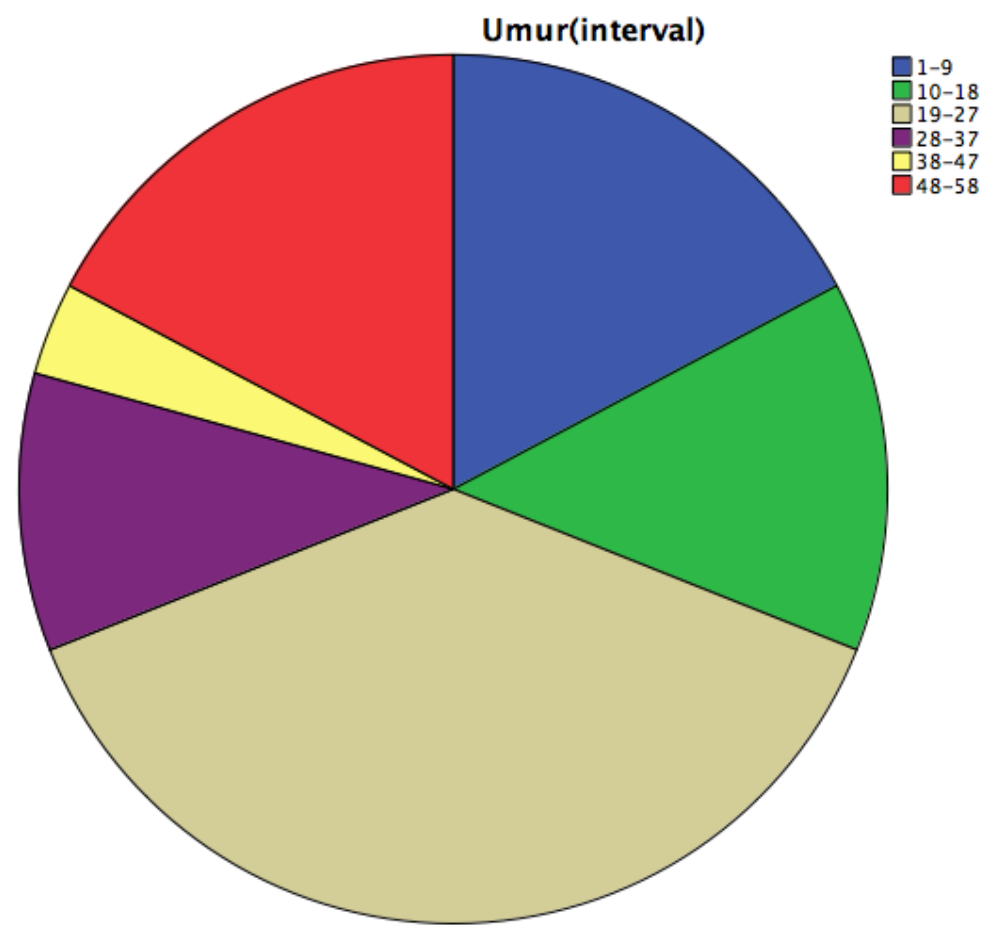

Sumber: data primer penelitian

Berdasarkan tabel 4.2. dan diagram ini, menunjukkan bahwa presentasi responden dari 29 pasien, sebagai berikut: usia 1-9 tahun sebanyak 5 pasien (17,2\%), usia 10-18 tahun sebanyak 4 pasien (13,8 \%), usia 19-27 tahun sebanyak 11 pasien (37,9\%), usia 28-37 tahun sebanyak 3 pasien (10,3\%), usia 38-47 tahun sebanyak 1 pasien (3,4\%) dan usia 48-58 sebanyak 5 pasien $(17,2 \%)$.

Setelah melakukan hasil isolasi dan identifikasi bakteri terhadap sampel darah pasien, ditemukan bakteri-bakteri penyebab sebagai berikut: bakteri Alkaligenes faecalis sebanyak 4 pasien (13,8 \%), TAP sebanyak 16 pasien (55,2 \%), Klebsiella aerogenes sebanyak 3 pasien (10,3\%), Klebsiella pneumonia sebanyak 1 pasien (3,4 \%), Salmonella Paratyphi A sebanyak 1 pasien $(3,4 \%)$, dan Salmonella typhi sebanyak 4 pasien $(13,8 \%)$. 
Tabel 4.3. Prevalensi pasien gejala suspek Demam Typhoid berdasarkan hasil isolasi dan identifikasi sampel $(n=29)$

\begin{tabular}{l|c|c}
\multicolumn{1}{c|}{ Jenis Bakteri } & Frekuensi & Persen (\%) \\
\hline Alkaligenes Faecalis & 4 & 13.8 \\
\hline TAP (tidak ada pertumbuhan) & 16 & 55.2 \\
\hline Klebsiella Aerogenes & 3 & 10.3 \\
\hline Klebsiella Pneumonie & 1 & 3.4 \\
\hline Salmonella Paratyphi A & 1 & 3.4 \\
\hline Salmonella Typhi & 4 & 13.8 \\
\hline Total & 29 & 100.0
\end{tabular}

Sumber: data primer penelitian

Gambar 8. Diagram prevalensi pasien gejala suspek Demam Typhoid berdasarkan hasil isolasi dan identifikasi sampel

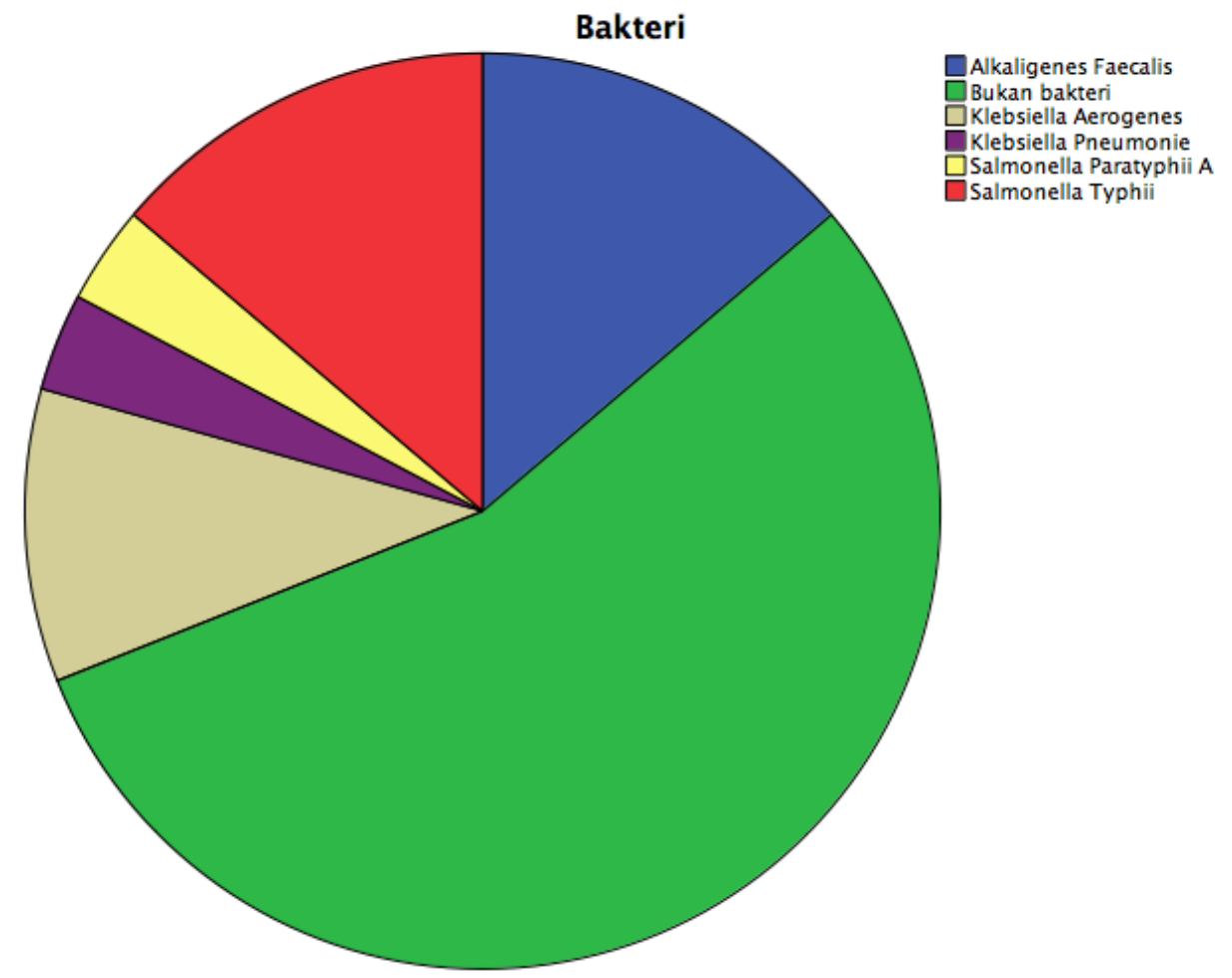

Sumber: data primer penelitian 


\subsection{PEMBAHASAN}

\subsubsection{Jenis Kelamin}

Menurut karakteristik jenis kelamin, hasil penelitian ini menunjukkan bahwa jenis kelamin terbanyak pasien bergejala demam Typhoid di Rumah Sakit Ibnu Sina pada bulan Juli-Agustus 2016 adalah laki-laki sebanyak 17 pasien $(58,6 \%)$.

Serupa dengan penelitian yang dilakukan oleh Yulinda Novita di Rumah Sakit UIN Syarif Hidayatullah Jakarta 2008-2009 menunjukkan bahwa insiden terbanyak terjadi pada jenis kelamin laki-laki sebanyak 134 pasien dari 244 pasien sedangkan pada jenis kelamin perempuan sebanyak 110 pasien. Pada penelitian ini, prevalensi pasien bergejala demam Typhoid yang berjenis kelamin perempuan sebanyak 12 pasien (41,4\%). Begitu pula menurut Jurnal Kesehatan Volume 8 Fakultas MIPA dengan 182 kasus Demam Typhoid menunjukkan bahwa jenis kelamin terbanyak yaitu laki-laki sebanyak 101 pasien $(55,49 \%)$ dan 81 pasien $(44,51 \%)$ pada perempuan. $^{26,27}$

\subsubsection{Usia}

Menurut karakteristik usia, hasil penelitian ini menunjukkan bahwa usia tertinggi pasien gejala demam Typhoid di Rumah Sakit Ibnu Sina pada bulan Juli-Agustus 2016 adalah usia 1927 tahun sebanyak 11 pasien (37,9\%) dan terendah usia 38-47 tahun sebanyak 1 pasien $(3,4 \%)$ seperti pada penelitian yang dilakukan oleh Rohman di Rumah Sakit Islam Roemani tahun 2000 bahwa prevalensi terbanyak pasien bergejala demam Typhoid menurut usia adalah umur 15-24 tahun ( $28 \%$ ), dan sisanya dari kelompok umur 5-14 tahun ( $27 \%$ ), kelompok umur 24-34 tahun ( $13 \%$ ), sedangkan Demam Typhoid yang terendah adalah kelompok umur 55-64 tahun ( $1 \%$ ). Menurut penelitian yang dilakukan oleh Nadyah di Kelurahan Samata Kecamatan Somba Opu Kabupaten Gowa tahun 2013, pasien bergejala demam Typhoid usia > 20 tahun $(78 \%)$ lebih tinggi prevalensinya dari usia $<20$ tahun $(22 \%){ }^{28,29}$

\subsubsection{Hasil Isolasi dan Identifikasi Sampel}

Setelah mendapatkan sampel darah pasien dengan gejala Demam Typhoid di Rumah Sakit Ibnu Sina, kami membawa sampel ke Laboratorium Mikrobiologi Fakultas Kedokteran UMI (sampel diinjeksi dalam Medium Transport / tabung Antikoagulan dalam suhu $<37^{0}$ untuk mencegah matinya sel mikroba) lalu mengisolasinya dengan medium Nutrient Agar dan Mac Conkey (NA untuk enrichment dan kultur berbagai bakteri lalu Medium Mac Conkey untuk membedakan yang memfermentasi laktosa dan tidak, seperti Salmonella \& Shigella) selama 1-2 
hari, bila ditemukan pertumbuhan bakteri (pertambahan secara teratur semua komponen suatu organisme, bukan sel yang menyerap air, akumulasi lemak/polisakarida, atau kontaminasi hal lain), kami lanjut melakukan identifikasi bakteri dengan Tes Biokimia, bila hasil negatif (tidak ada pertumbuhan bakteri dari sampel penelitian/ proses pengambilan sampel), penelitian tidak kami lanjutkan., ${ }^{2,30,31}$

Setelah dilakukan tes biokimia, sampel didiamkan dalam autoklaf selama 1-2 hari, lalu dilakukan identifikasi jenis bakteri pada sampel, didaptkan hasil bakteri Alkaligenes faecalis sebanyak 4 pasien (13,8 \%), tidak ada pertumbuhan sebanyak 16 pasien (55,2\%), Klebsiella aerogenes sebanyak 3 pasien (10,3\%), Klebsiella pneumonia sebanyak 1 pasien (3,4\%), Salmonella Paratyphi A sebanyak 1 pasien (3,4 \%), dan Salmonella typhi sebanyak 4 pasien $(13,8 \%)$.

Menurut hasil penelitian eksperimental ini ditemukan berbagai penyebab gejala Demam Typhoid pada 29 sampel, sebagai berikut:

1. Salmonella typhi : sesuai pada kepustakaan bab II bahwa bakteri etiologi Demam Typhoid adalah Salmonella typhi dan Salmonella paratyphi A.

2. Salmonella paratyphi A : sesuai pada kepustakaan bab II bahwa bakteri etiologi Demam Typhoid adalah Salmonella typhi dan Salmonella paratyphi A.

3. Klebsiella aerogenes : bakteri gram negative berkapsul polisakarida yang habitat alaminya di saluran cerna manusia dan hewan. Grup Klebsiella menyebabkan pathogenesis penyakit dengan faktor nonspesifik serupa dengan E.Coli seperti pada pasien ISK, diare, sepsis, dan meningitis. Tidak ada terapi spesifik tunggal, efek antibakteri sulfonamide, ampisilin, sefalosporin, fluorokuinolon, dan aminoglikosida bermakna terhadap bakteri enterik tetapi dengan spesifitas yang sangant bervariasi. ${ }^{2}$

4. Alkaligenes faecalis : salah satu bakteri basil gram negatif berflagela peritriks, dapat merupakan bagian flora bakteri normal pada manusia namun juga dapat ditemukan pada pasien ISK. $^{2}$

5. Klebsiella pneumonie : bakteri basil gram negative enterik dan habitat alaminya di saluran cerna manusia dan hewan. Grup Klebsiella menyebabkan pathogenesis penyakit dengan faktor nonspesifik serupa dengan E.Coli seperti pada pasien ISK, diare, sepsis, dan meningitis. ${ }^{2}$ 
6. TAP (Tidak Ada Pertumbuhan) : hasil kultur bakteri negative, namun, hasil negatif tidak menyingkirkan diagnosa Demam Typhoid, karena hasilnya tergantung pada beberapa faktor. Faktor-faktor yang mempengaruhi hasil biakan meliputi jumlah darah yang diambil, perbandingan volume darah dari media empedu, waktu pengambilan darah, dan bisa juga disebabkan oleh mikroba lainnya selain bakteri, seperti virus, $\mathrm{dll} .{ }^{9}$

Menurut penelitian mengenai Demam Typhoid pada anak di Kenya tahun 2000 bahwa menonjolnya global dan tingginya profil wabah Typhoid telah menciptakan persepsi bahwa Typhoid merupakan penyebab umum dari penyakit demam. ${ }^{33}$

Pada penelitian Agus Sjahrurachman, Bagian Mikrobiologi FK UI pada tahun 2003, diagnosis demam enteric/ Typhoid sering dilakukan secara klinis saja. Namun demikian berbagai hasil penelitian menunjukkan bahwa gambaran klinis awal penyakitnya sangat menyerupai berbagai gambaran klinis penyakit infeksi lain. Karena itu penegakkan diagnosis pada awal penyakit memerlukan konfirmasi pemeriksaan mikrobiologi walaupun mempunyai banyak keterbatasan: lamanya hasil pemeriksaan, masa bakterimia/antigenemia terbatas, sukarnya penanganan specimen yang baik, dan kebiasan pemberian antibiotik pada pengobatan empiric. Namun berbagai teknologi telah dikembangkan belum distandarisasi sehingga sensitifitasnya masih beragam, pemeriksaan felix-widal salah satu contohnya. ${ }^{34}$

Sementara pada peninjauan literatur penelitian di Kenya pada tahun 2000 yang menyusun informasi tentang prevalensi Typhoid pada anak-anak dan mengeksplorasi peran diagnosis klinis dan interpretasi tes Widal, data menunjukkan bahwa Typhoid pada anak-anak di pedesaan Afrika jarang, atau mungkin 100 kali atau 250 kali umunya penyakit invasif disebabkan Haemophilus influenza, Streptococcus pneumonia, atau lainnya. Seringnya menggunakan tes Widal mengakibatkan ratusan lebih pengobatan untuk setiap kasus menyatakan persepsi sebagai kasus Typhoid..$^{33}$

Yang disayangkan pula adalah menurut penelitian Punjabi, dampak sosial ekonomi akibat penyakit demam enteric diperkirakan sangat besar. Dengan memperhitungkan biaya pengobatan, Punjabi berhasil memperkirakan bahwa kerugian yang diderita oleh bangsa Indonesia untuk pengobatan secara finansial hingga 120 juta dollar Amerika per tahun. ${ }^{34}$ Sementara tingkat resistensi antibiotik dan resiko bakteremi meningkat (kloramfenikol 10\%). ${ }^{35}$ 


\section{BAB V}

\section{KESIMPULAN DAN SARAN}

\subsection{Kesimpulan}

1. Prevalensi angka kejadian Demam Typhoid di Rumah Sakit Ibnu Sina Makassar bulan Juli-Agustus 2016 sebanyak 40 pasien.

2. Dari hasil penelitian ini dapat disimpulkan bahwa pada kasus 29 pasien bergejala Demam Typhoid di Rumah Sakit Ibnu Sina Juli-Agustus 2016 prevalensi pada laki- laki lebih tinggi daripada pada perempuan [laki-laki sebanyak 17 pasien $(58,6 \%)$ dan perempuan sebanyak 12 pasien $(41,4 \%)]$.

3. Prevalensi pasien bergejala Demam Typhoid di Rumah Sakit Ibnu Sina Juli-Agustus 2016 lebih tinggi pada usia 19-27 tahun sebanyak 11 pasien $(37,9 \%)$.

4. Menurut hasil isolasi dan identifikasi sampel darah pasien bergejala Demam Typhoid di Rumah Sakit Ibnu Sina Juli-Agustus 2016, tidak hanya ditemukan bakteri Salmonella typhi / Salmonella paratyphi tetapi terdapat etiologi lain ( Salmonella typhii 13,8 \%; Salmonella paratyphii A 3,4 \%, Tidak Ada Pertumbuhan (TAP) 55,2 \%; Alkaligenes faecalis sebanyak 13,8 \%; Klebsiella aerogenes sebanyak 10,3\%; Klebsiella pneumonia sebanyak $3,4 \%)$.

\subsection{Saran}

1. Bagi Instansi terkait:

Dari hasil penelitian ini diharapkan dapat menjadi informasi bagi instansi terkait agar dilakukan pemeriksaan mikrobiologi bagi pasien bergejala Demam Typhoid selain pemeriksaan klinis dan widal sehingga pemberian terapi antibiotik dapat menjadi lebih spesifik dan mengurangi resiko resistensi ataupun bakteremia.

2. Bagi peneliti selanjutnya:

Diharapkan dapat menjadi dasar penelitian mengenai Demam Typhoid atau penyakit lain yang bergejala klinis serupa sehingga dapat diketahui lebih lanjut mengenai diagnosa klinik yang bijak dan tepat serta terapi yang efisien dan efektif. 


\section{Bagi masyarakat:}

Semoga tingkat pengetahuan masyarakat mengenai Demam Typhoid dan antibiotik terus meningkat sehingga dapat dilakukan pencegahan terhadap resistensi antibiotik ataupun resiko bacteremia. 


\section{DAFTAR PUSTAKA}

1. Julius, E.S. 1990 Mikrobiologi Dasar. Jakarta: Binarupa Aksara Latar

2. Jawetz E, etc.2012. Mikrobiologi Kedokteran. Ed 25. Jakarta:EGC

3. Widoyono. 2008. Penyakit Tropis, Epidemiologi, Penularan, Pencegahan, dan Pemberantannya. Jakarta; Erlangga

4. Nasronudin. 2011. Demam Tifoid. In: Nasronudin, Usman H, MV, Astha TE, Bramantono, Suharto, et al., editors Penyakit Infeksi di Indonesia Solusi Kini dan Mendatang Ed 2. P. 187-9. Surabaya: Pusat Penerbitan dan Percetakan UNAIR

5. Widodo J. 2009. Demam Tifoid. In: Sudoyo AW, Hadi BS, Alwi I, Simadribrataka M, Setiati S, editors. Nuku Ajar Ilmu Penyakit Dalam ed.5 . P.2798-2802. Jakarta Pusat: Interna Publishing Pusat Penerbitan Ilmu Penyakit Dalam

6. Muliawan, S.Y dan Julius E.J, 1999. Tinjauan Ulang Peranan Uji Widal sebagai Alat Diagnostik Penyakit Demam Tifoid di Rumah Sakit. Jakarta: Cermin Dunia Kedokteran no. 124

7. Algerini, A. 2008. Demam Tifoid dan Infeksi lain dari Bakteri Salmonella. [online]. [diakses tanggal 5 Mei 2016 http://medicastore.com/penyakit/10/demam tifoid.html]

8. Darmowandowo, T. 2006. Demam Tifoid: Buku Ajar Ilmu Kesehatan Anak: Infeksi \& Penyakit Tropis, edisi 1. Jakarta: BP FK UI

9. Sudoyo, A.W.etc. 2007. Buku Ajar Ilmu Penyakit Dalam. Jakarta: FK UI

10. Soedarmo. Dkk. 2008. Buku Ajar infeksi dan penyakit tropis edisi kedua, Jakarta: Ikatan Dokter Anak Indonesia

11. Putra, A. 2012. Hubungan Antara Tingkat Pengetahuan Ibu Tentang Demam Tifoid Terhadap Kebiasaan Jajan Anak Sekolah Dasar.Semarang. FK UNDIP

12. Nainggolan, R.N.F. 2009. Karakteristik Penderita Demam Tifoid Rawat Inap Di Rumah Sakit Tentara TK-IV 01.07.01 Pematangsiantar Tahun 2008. Medan: FK USU

13. Crump JA dan Luby SP. 2004. The Global Burden of Typhoid Fever. Bull WHO Organ $82: 346-353$

14. Rahayu E. 2013. Sensitivitas Uji Widal dan Tubex untuk Diagnosis Demam Tifoid Berdasarkan Kuktur Darah. Semarang : Universitas Muhammadiyah Semarang

15. Brooks, G.F.dkk.2001. Mycobacteriaceae in Jawetz Medical Microbiologi, 22ed. Newyork: McGraw-Hill Companies 
16. Salyers A dan Whitt D. 2002. Bacterial Pathogenesis: A Molecular Approach $2^{\text {nd }}$ Edition. Wahington DC: ASM Press

17. Rustandi D dan Melda S. 2010. Demam Tifoid. Bandung: Universitas Padjajaran

18. Marleni M. 2012. Ketepatan Uji Tubex TF Dibandingkan Nested-PCR dalam Mendiagnosisi Demam Tifoid pada Anak Demam Hari Ke-4. Palembang: FK UNSRI

19. Hoffman,SL. 2002. Typhoid Fever. In: Strickland GT/ Editor. Haunter's Tropical Medicine. $7^{\text {th }}$ ed Philadephia: WB Saunders Co.

20. WHO (World Hea;th Organization). Background Doc: The Diagnosis, Treatment and Prevention of Typhoid Fever 2003. Genewa, Switzerland

21. Hardi, S. Dkk. 2002. The Diagnostic Value of The Widal Test in Typhoid Fever Patients. In: Typhoid Fever: Profil, Diagnostic, and Treatment in 2001. $1^{\text {st }}$ ISAC International Symposium: Acta Medica Indonesia

22. Wain J, Hosoglu S. 2008. The Laboratory Dignosis of Enteric Fever. Journal of Infection in Developing Countries 2 (4): 260-266

23. Handoyo,I. 2004. Diagnosis Laboratorium Demam Tifoid. Jurnal Kimia Klinik Indonesia

24. Braunwald. 2005. Harrison's Principles of. Internal Medicine. 16th Edition. New York: Mc Graw Hill

25. Soewondo ES. 2002. Demam tifoid deteksi dini dan tatalaksana. Makalah lengkap: Seminar Kewaspadaan terhadap demam pada penyakit typhus Abdominalis, DBD dan Malaria Serta Penggunaan Tes Diagnostik Laboratorium untuk Deteksi Dini. Surabaya:Tropical Diseases Centre UNAIR.

26. Novita, Yulinda. 2009. Prevalensi Demam Typhoid Berdasarkan Jenis Kelamin Pada Pasien Rawat Jalan di Rumah Sakit UIN Syarif Hidayatullah Jakarta Dari Bulan Juli 2008 Sampai Juli 2009. [dikutip 1 September 2016]. Available from: http://repository.uinjkt.ac.id/dspace/bitstream/123456789/26430/1/YULINDA\%20NOVI TA-FKIK.pdf

27. Musnelina, Lili,dkk. Juni 2004. Pola Pemnerian Antibiotika Pengobatan Demam Tifoid Anak di RS Fatmawati Jakarta Tahun 2001-2002. Makara Kesehatan vol 8 no 1 hal 2731 
28. Rohman. 2000. Distribusi Penderita Demam Tifoid Menurut Umur dan Gejala di RS Roemani tahun 2000. [dikutip 1 September 2016]. Available form: http://jurnal.unimus.ac.id/index.php/psn12012010/article/view/51

29. Nadyah. 2013. Hubungan Faktor-Faktor Yang Mempengaruhi Insiden Penyakit Demam Tifoid di Kelurahan Samata Kecamatan Somba Opu Kabupaten Gowa Tahun 2013.[dikutip 1 September 2016]. Available form: http://journal.uinalauddin.ac.id/index.php/kesehatan/article/view/948

30. Gandasubrata, R. 2004. Penuntun Laboratorium Klinik. Jakarta: DianRakyat

31. Herawati, Iis. Dkk. 2013. Modul penuntun prkatikum mikrobiologi II (edisikedua). Cimahi: Stikes Jenderal Achmad Yani

32. Mangarengi, Yusriani dan Madjid, Baedah. 2015. Penuntun Praktikum Mikrobiologi Sistem Urogenital. Makassar: Bagian Mikrobiologi FK UMI

33. Mweu, Evanson dan English, Mike. 2000. Typhoid Fever in Children in Kenya. [dikutip 4 September 2016]. Available from:

http://www.ncbi.nlm.nih.gov/pmc/articles/PMC2660514/

34. Sjahrurachman, Agus, dkk. Mei 2003. Profil Respon Imun Humoral terhadap Flagel Salmonella pada Kelinci. Jakarta: Bagian Mikrobiologi FK UI.

35. Sjahrurachman, Agus. Juli 2004. Profil Etiologi Bakteremi dan Resistensinya terhadap Antibiotik di RS Cipto Mangunkusumo Jakarta tahun 1999-2002. Jakarta: Bagian Mikrobiologi FK UI 